Article

\title{
Performance-Based Fire Engineering Design of a Heritage Building: McDougall House Case Study
}

\author{
Dennis Pau ${ }^{1, * \mathbb{B}}$, Christine Duncan ${ }^{2}$ and Charles Fleischmann ${ }^{1}$ \\ 1 Department of Civil and Natural Resources Engineering, University of Canterbury, \\ Christchurch 8140, New Zealand \\ 2 Norman Disney \& Young, Wellington 6011, New Zealand \\ * Correspondence: dennis.pau@canterbury.ac.nz; Tel.: +64-21-182-6058
}

Received: 6 June 2019; Accepted: 12 July 2019; Published: 17 July 2019

\begin{abstract}
The application of a performance-based fire engineering design has enabled the conservation of a heritage building in New Zealand. McDougall House is a two-story heritage building which suffered extensive damages during the Canterbury earthquakes in 2010 and 2011. The scope of the conservation plan included the preservation and restoration of the building external façade, the restoration of the ornamental plasterwork ceiling within the Ballroom, the reconstruction of all damaged internal lath and plaster linings, the adaptation of the fireplace, and the reconstruction of the damaged chimney. The fire engineering design adopted is the Verification Method C/VM2 with As Nearly As is Reasonably Practicable consideration for the heritage fabrics of the building. The combination of quantitative and qualitative analyses has demonstrated the building design compliance with the 10 design scenarios of C/VM2. These analyses include the assessment of minimum means of escape and fire protection provisions, the assessment of allowable unprotected areas in the external wall for horizontal fire spread, the assessment of firefighting provisions, the smoke and egress modelling of proposed design fires, and the benefit versus sacrifice analysis on the heritage fabrics. The application of C/VM2 results in an upgrade to the fire safety and fire protection systems of the building while also retaining and enhancing its heritage value.
\end{abstract}

Keywords: cultural heritage; performance-based fire engineering design; fire protection design; zone smoke modelling; required safe egress time; available safe egress time

\section{Introduction}

Heritage buildings represent the intrinsic fabric of a society that amass historical values over time, conveying invaluable information from the past to the present and future communities. The accrued cultural heritage values are the identity of the society in relation to its ancestors and are also a measure of the achievement of the current community [1]. The construction of heritage buildings is often unconventional when compared to the current standard of practice [2] also with on-going use and the associated conservation process, which would require the buildings to be assessed according to the current building regulatory requirements. Therefore, it is vitally important to ensure that the cultural heritage values intertwining the past, present and future are not lost in the process of complying with the building regulations. This presents a rather unique challenge from the fire engineering perspective. The International Council on Monuments and Sites (ICOMOS)'s New Zealand Charter [1] outlines the conservation principles of heritage places, including buildings and landscapes. The approach comprises preservation, restoration, reconstruction and adaptation with emphasis on minimizing loss or damage to the heritage values.

This paper presents the details of the performance-based fire engineering design for a heritage building in New Zealand, the McDougall House [3]. The two-story, Arts and Crafts, Queen Anne and 
Classical architecture-styled building is located at $24 \mathrm{McDougall}$ Avenue, in the suburb of Merivale, Christchurch [4]. The building originally named Fitzroy was designed by local architects, the England Brothers, and constructed in 1898 as the residential home for Robert Ewing McDougall. Since then, the building has undergone a number of prominent changes, listed chronologically: the addition of southern Ballroom in 1913, the enclosing of external verandas with bay windows and the addition of eastern gable before 1932, and the replacement of the original turret with gable between 1930s and 1940s. In 1949, McDougall House was gifted to Nurse Maude Association. Following some alterations, including the addition of multiple external fire stairs from the first floor, the building had a change of use to operate as a convalescent home from 1950. McDougall House had another change of use in 1964, from the hospital accommodation to an administration center for the association. The last pre-earthquake major renovation was in 1993 during which the fire escape stairs were removed. Following the 2010 and 2011 Canterbury earthquakes, major conservation was carried out from 2013 to 2015. Figure 1 shows the physical changes of the building by comparing the original building exterior in 1898 with the current completed in 2015.

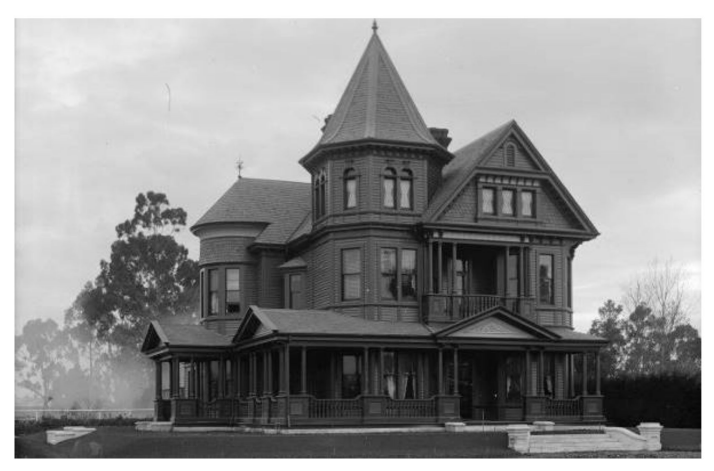

(a)

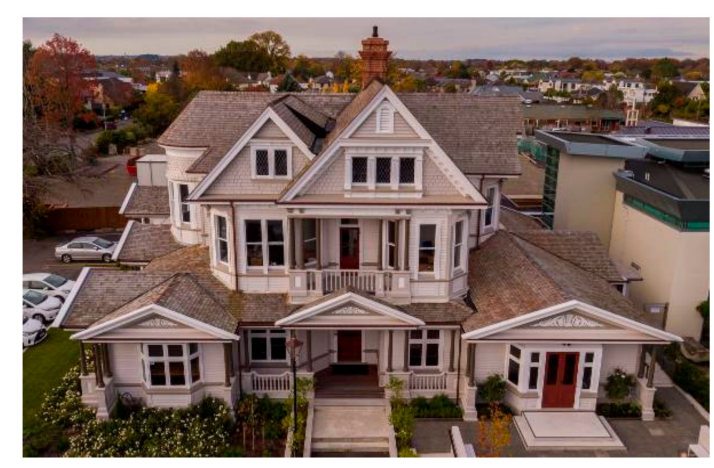

(b)

Figure 1. Exterior appearance of McDougall House: (a) Original western elevation in 1898 reproduced with permission (Fitzroy, a house on Papanui Road, Christchurch. Ref: 1/2-074020-G. Alexander Turnbull Library, Wellington, New Zealand. https://natlib.govt.nz/records/22764051); (b) Current western elevation upon completion of refurbishment in 2015.

Currently, the newly refurbished McDougall House remains as the office and business administration center of Nurse Maude Association, the primary focus of which is the nursing, homecare and health support of patients. This paper discusses the qualitative and quantitative methodologies applied as part of the performance-based fire engineering design of McDougall House in line with its heritage conservation plan. A summary of the fire engineering design was previously presented in a conference proceeding [5] and this paper is an expansion of the former.

\section{Earthquake Damages and Conservation of McDougall House}

According to the earthquake assessment report [6], prior to the earthquakes, McDougall House was a timber-framed structure with timber weatherboard as exterior cladding and timber shingles as roofing. Internally, the wall and ceiling linings were predominantly a lath and plaster construction with a small amount of plasterboard linings, and the first floor was a timber joist construction. Between 2010 and 2011, McDougall House experienced two earthquakes and numerous aftershocks. The first earthquake was on 4 September 2010 with a depth of $10 \mathrm{~km}$ and a magnitude of 7.1, generating $1.26 \mathrm{~g}$ of peak ground acceleration. The resulting damages to the building included significant damage to a reasonable number of lath and plaster walls which have inherently inferior bracing capacity. Minor cracking was also noted to the ceiling, first floor and chimneys, and there was misalignment in the ground floor level. In an effort to secure the chimneys, the portion within and above the roof was removed subsequently. The second earthquake occurred on 22 February 2011, with a depth of $5 \mathrm{~km}$ and a magnitude of 6.2 , generating $2.20 \mathrm{~g}$ of peak ground acceleration. This time, there were extensive 
damage to the already weakened lath and plaster walls and floors from the prior earthquake and aftershocks. The damages were more severe towards the west end of the building due to the presence of the two chimneys, which added more seismic mass during the shakes, and this was amplified by a lack of bracing walls within that area of the building. The chimneys were badly damaged and have to be removed due to the imminent risk of collapse. Figure 2 shows some examples of these internal damages throughout the building.

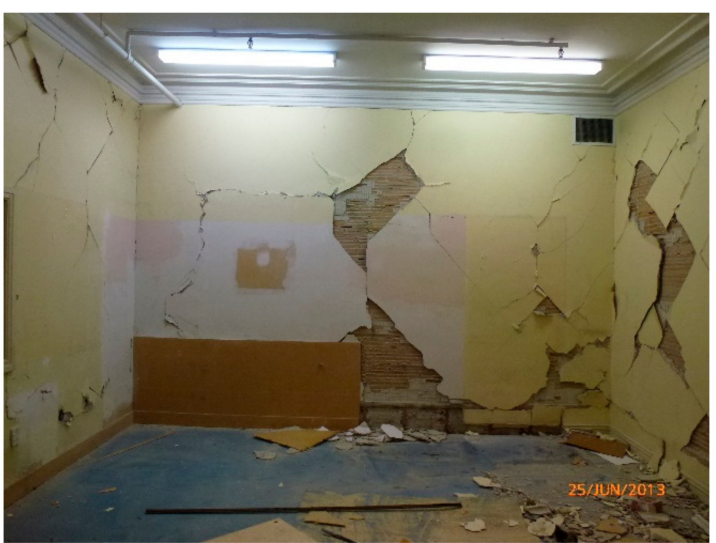

(a)

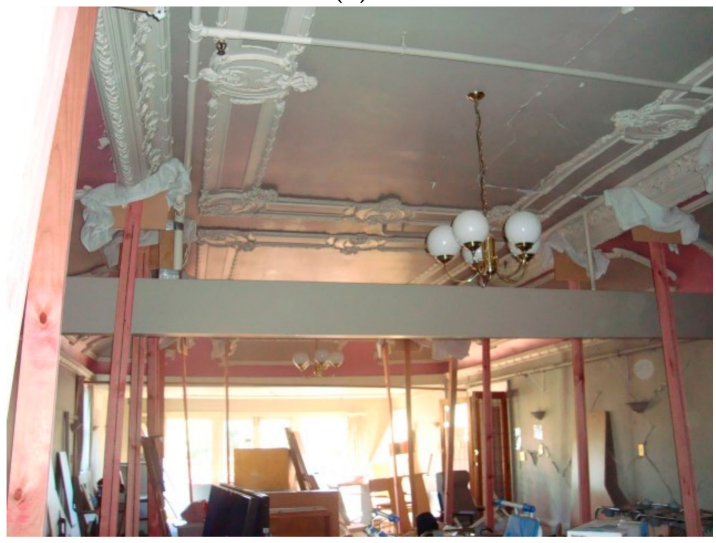

(c)

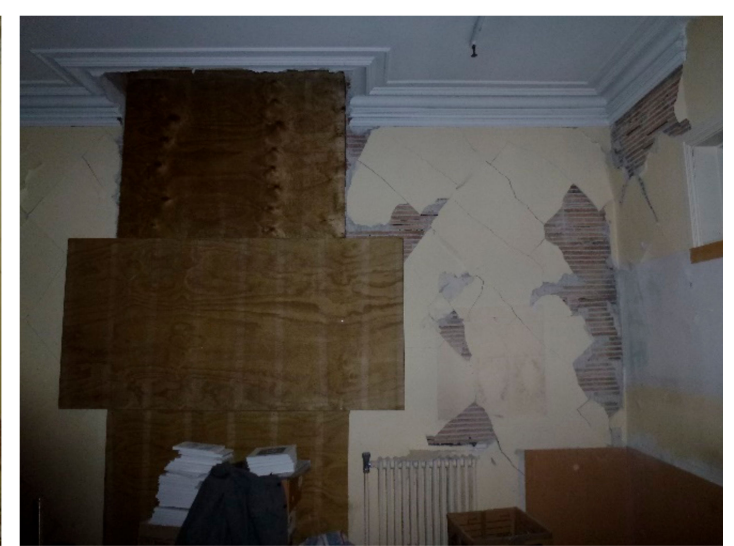

(b)

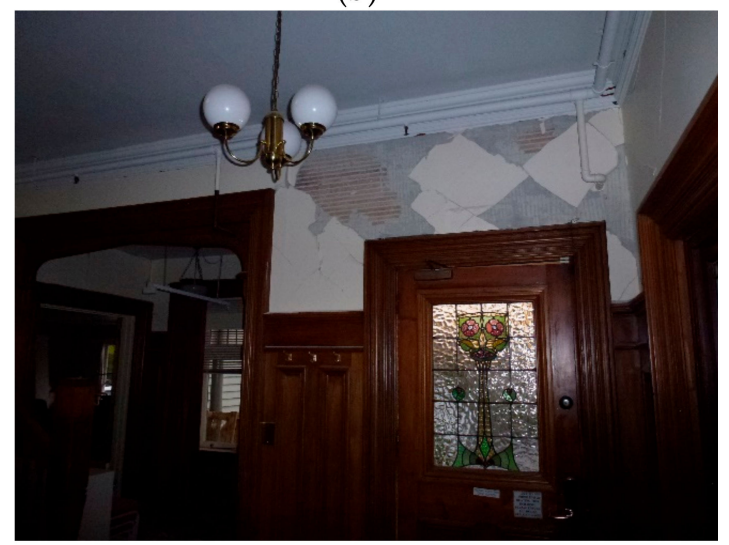

(d)

Figure 2. Typical interior damages throughout McDougall House: (a) Damages on lath and plaster walls; (b) Section of a removed chimney; (c) Cracked ornamental plasterwork ceiling in the Ballroom;

(d) Damages on a composite lath and plaster wall with heritage timber linings.

The heritage survey [4] identified a number of exterior and interior building elements of cultural heritage significance. Externally, as seen in Figure 1, these included the original feature windows, gables and associated pediments, eave and ornate brackets, veranda columns and balustrades, balcony details, shingled roofs, and timber weatherboard and timber tile cladding with original exterior trims. Internally, there was significant utilization of heritage timber features such as skirting, paneling, trims, post and beam structure, arch, doors and stairs, and a few ornamental heritage plasterwork, particularly the Ballroom's ceiling which was with coved cornice and a number of ceiling roses distributed throughout. Despite the severity of the shakes, the external damages were cosmetic only and did not require significant repairs or replacements. However, the internal heritage damages were more significant. The removal of two badly damaged chimneys and associated fireplaces constituted an irreparable loss of heritage significance as seen in Figure $2 \mathrm{~b}$. The ornamental plasterwork ceiling within the Ballroom was cracked as seen in Figure 2c, requiring delicate restoration.

Besides earthquake damages, a preliminary review on the services of McDougall House revealed that the ventilation, hydraulic and electrical systems will require an upgrade to comply with the current New Zealand Building Code (NZBC) requirements. Similarly, in regards to fire safety, the addition of 
new fire protection systems and upgrade to the existing will be needed to achieve an acceptable level of fire safety for McDougall House. These included repair to damaged walls and floors, including vertical voids left by the removed chimneys which compromised the fire resistance rating and smoke stopping capability of these elements. A number of existing fire protection systems were also deemed intrusive, detracting the heritage importance of the building, such as exposed sprinkler pipework and heads under the ornamental plasterwork ceiling noted in Figure 2c, and an exposed fire hose reel mounted on the wall. Some fire protection technologies were considered obsolete by current standards such as brass pendant sprinkler heads, bell-type sounders, doors with Georgian wired glass, outdated emergency lighting with limited coverage and reflective exit signage. While fire-stopping of service penetrations through fire-rated construction is currently considered as a standard practice, at the time of the last renovation in 1993, this was relatively unknown. Thus, McDougall House has a number of untreated services penetrations throughout, resulting in incomplete fire and smoke separations where required.

The conservation strategy adopted has an in-depth consideration of the building's cultural heritage importance, in line with International Council on Monuments and Sites (ICOMOS) conservation principles to maintain the authenticity and integrity of McDougall House. The building's foundation was strengthened with hundreds of new piles and a few ground beams, and the timber-framed structure was supported by additional steel and timber bracing frames throughout. Externally, the proposed refurbishment included restored veranda decking on the northern elevation, new exterior paving and landscape along the eastern elevation, a new southern entry and restored western entry of the Ballroom, the replacement of damaged weatherboards and the application of new paint. Internally, the layout of a few offices and stores at the ground and first floor were revised. There were also alterations to the existing toilets and additions of new ones. The fireplace and chimney within the Boardroom were sealed while a new fireplace and associated chimney shaft were adapted for the Ballroom. The extensively damaged lath and plaster walls were replaced with either plasterboard on an existing lath substrate or on new timber frame, or as a composite wall of heritage timber panels on lath and plaster with mineral wool in the cavity on one side and new plasterboard wall on the other. The new floor ceiling system was plasterboard on timber joist floor, replacing the damaged lath and plaster. On pre-earthquake floor plans, Figure 3 highlights the proposed alterations, where red and green colors denote the external and internal works, respectively.

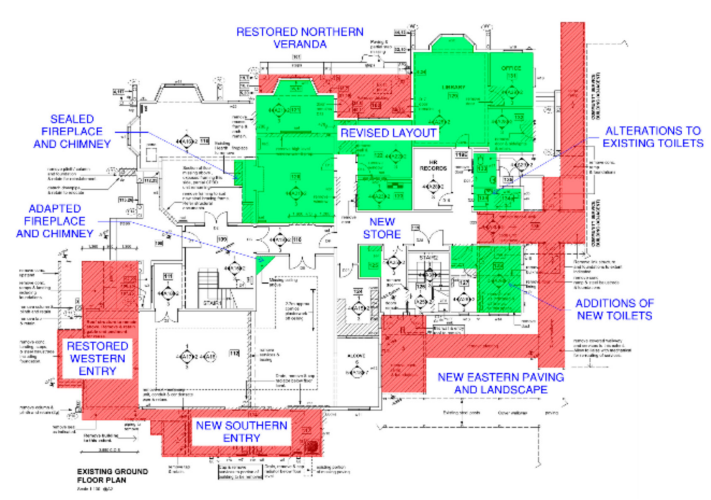

(a)

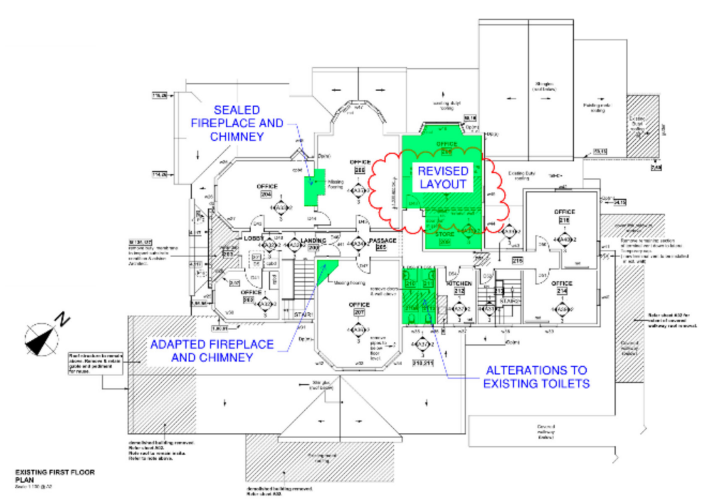

(b)

Figure 3. Proposed alterations for the conservation of McDougall House: (a) Ground floor; (b) First floor.

At the completion of the refurbishment, the building layout remained similar in essence to how it was pre-earthquake. Figure 4 shows the current floor plan of both floors with the expected occupant distribution, the designated exits and the demarcation of fire and smoke separations. Some information relates to the outcomes of the performance-based fire engineering design, which will be elaborated in the subsequent sections. The ground floor comprises a number of partitioned offices and meeting 
rooms, Ballroom, Boardroom and miscellaneous spaces such as stores, kitchen and toilets. This level is served by a number of final exits which lead directly to the outside carpark and linkway. A partitioned corridor interconnects the ground spaces to the two stairs serving the first floor located at opposite ends of the corridor. These are open feature stairs with a main ground lobby and an enclosed stair. The first floor contains additional office spaces with a kitchen and toilets. This upper level has a single means of escape for fire safety via the enclosed stair with the open feature stair for convenient access only. The enclosed stair is bounded by the fire separation with smoke stopping capability, indicated by the red line, while the open feature stair is smoke separated at the first floor by the smoke separation indicated by the cyan line. Based on the floor area and occupant densities for the designated use of the spaces throughout [7], the total occupant load of McDougall House is 95 with 79 and 16 at ground and first floor, respectively.

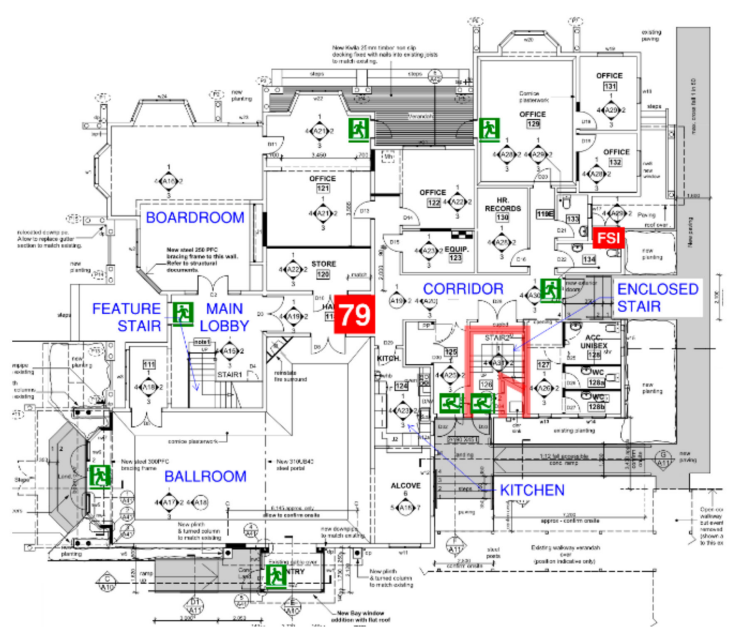

(a)

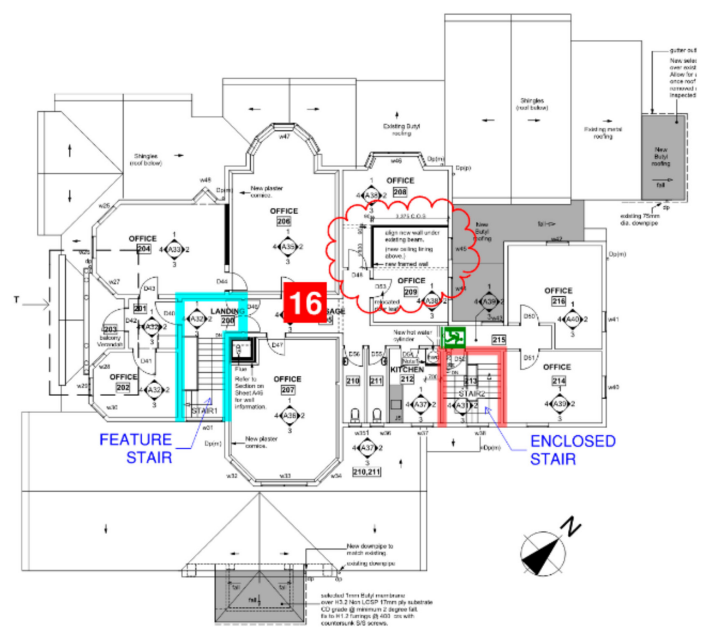

(b)

Figure 4. Current layout of McDougall House: (a) Ground floor; (b) First floor.

\section{Building Control System within New Zealand}

In New Zealand, the Building Act 2004 [8] is the mandatory building control framework within the country which governs the building design and construction process. The aims are to improve the control of building design and construction practice, to ensure the health and safety of building occupants, and to promote sustainable development. A few sections of the Building Act provide clarity on the minimum fire safety requirements for a building, according to its status and use. First, Section 17 states that all building work, including fire safety, must comply with the NZBC and this provides an overarching provision covering major work such as a new built and also minor ones not requiring a building consent. Second, Section 112 specifically addresses alterations to existing buildings where, after alterations, the means of escape from fire needs to comply with NZBC provisions or on a As Nearly As is Reasonably Practicable (ANARP) basis. Lastly, Section 115 covers buildings undergoing change of use, where a building under its new use will comply with every fire safety provision of the NZBC or on an ANARP basis. These include the means of escape from fire, protection of other property and fire rating performance. Change of use triggers more considerations on various aspects of fire safety when compared to alterations to the existing building only.

For McDougall House, Nurse Maude Association is retaining the existing building's use as office and business administration. Therefore, the proposed alterations for McDougall House are covered by Section 112, requiring the building after alterations to comply ANARP with NZBC in terms of means of escape from fire. In addition, the aspects relating to the protection of other property and fire rating performance were also considered by the fire engineering design. Protection of other property was reviewed due to the close proximity of McDougall House's southern elevation to an 
adjacent hospital, visible on the right side of Figure $1 \mathrm{~b}$. The hospital contains sleeping use and the alterations for McDougall House's new southern entry means the risk of fire spread has changed. Thus, a reassessment of the radiation exposure to boundary during fire is required. As mentioned in the previous section, the extensive earthquake damages to the wall and floor ceiling systems means the fire and smoke stopping performance were compromised. Thus, the fire resistance rating requires reassessment to specify suitable repairs or new systems. The ANARP provision requires the altered building to continue to comply with NZBC as before or, if it did not comply originally, the alterations will continue to comply with at least the same extent as before. For proposed alterations which do not meet NZBC, Section 112 also allows the territorial authority to permit such alterations if these result in improvements to the building, the improvements outweigh the adverse effects of not complying with NZBC, and if otherwise, such improvements would not occur. This allows some latitudes in the fire engineering design of existing cultural heritage buildings where reasonably justified deviations from the minimum NZBC requirements can be considered, provided the level of fire safety does not diminish following the alterations.

To meet the fire safety requirements of the Building Act, the building's fire engineering design needs to comply with NZBC's C1-C6 clauses, Protection from Fire [9]. The objectives of C clauses are to safeguard the people from unacceptable risk of injury or illness caused by fire, protect neighboring property from damage caused by fire, and facilitate firefighting and rescue operation. These objectives are satisfied by achieving the various performance criteria specific to each $C$ clause which contains a few functional requirements in general, such as reducing the likelihood of fire occurring via control of common building appliances, reducing the likelihood for internal and external fire spread, providing effective means of escape to facilitate evacuation in event of a fire, providing adequate firefighting provisions to facilitate fire service operation, and providing structural systems with adequate performance under conditions caused by fire. To demonstrate that the functional requirements and specific performance criteria are met, there are two types of design solutions: the prescriptive Acceptable Solutions [10] and the performance-based fire engineering design.

The prescriptive Acceptable Solutions C/AS1-C/AS7 often impose constraining design limitations when applied to existing cultural heritage buildings. From a fire safety perspective, typical design constraints include inadequate escape route characteristics, lack of fire and smoke stopping capability, unknown fire resistance rating of structural elements and unknown combustibility of surface linings. This is because the architectural features and construction materials predate many of the current design and construction practices, and there is also a lack of standard testing carried out to establish the performance of heritage building elements. The application of C/AS5 for McDougall House poses a challenge with the open feature stair which interconnects the ground and first floor. The first floor is considered as an intermediate floor due to the lack of fire and smoke separations surrounding the main ground lobby and at the top of the stair. As the size of the first floor exceeds the maximum allowable floor area of an intermediate floor in C/AS5, the prescribed solution would require forming the main ground lobby and feature stair as a firecell, separating from the adjacent ground and first floor spaces by fire- and smoke-rated constructions. This is not acceptable for the conservation plan because the installation of fire-rated walls and doors would result in the extensive removal of heritage timber linings. This solution remains costly, offers little value in terms of aesthetics, and yet significantly diminishes the heritage value of the building.

On the other hand, a performance-based fire engineering design approach offers more design flexibility to meet the requirements of NZBC C1-C6. Available options include Verification Method C/VM2 [7] and Alternative Solution. C/VM2 was developed based on New Zealand building stocks with the aim of ensuring greater consistency and certainty in fire engineering design at lower cost through a more efficient design and approval process. It is a fire safety design framework which prescribes a number design fire scenarios, design inputs and minimum performance outcomes in quantitative terms, allowing the designer to apply appropriate knowledge and modelling tools to assess the building's fire safety performance such as smoke transport, occupant evacuation and radiation 
to boundary or target. Despite having prescriptive requirements, C/VM2 still permits flexibility and innovation in building design whilst its level of complexity differentiates it from the fully prescriptive Acceptable Solution. From an approval perspective, the quantitative nature of the performance outcomes means the territorial authority can effectively regulate the fire safety level of buildings without having to assess the expected fire losses on a building-by-building basis.

Most building codes provide qualitative objectives so the selection of performance criteria and design fire scenarios for Alternative Solution are quantified by the designer and approved by the territorial authority to establish the level of fire safety. Traditionally, Alternative Solution covers the parts of building design which fail to meet the prescriptive solution as a variation showing compliance by means of engineering analysis. Wade et al. [11] and Fleischmann [12] have $d$ the common challenges encountered with Alternative Solution and the primary concerns are the inconsistent application of fire engineering and interpretation of fire safety level for essentially similar building occupancy. As a result, these building designs can vary considerably in terms of the fire safety and fire protection features incorporated due to the significant variations in design fire scenarios, design fires and performance criteria assessed. These complicate and delay the design, construction and approval process with adverse impacts on innovation and cost. Furthermore, many areas of Alternative Solution need further research such as the development of design fire scenarios by deterministic or probabilistic means, the improvement of design fire characteristics including species production, the representation of occupant response and evacuation in fire, and the selection and evaluation of performance criteria such as the fractional effective dose (FED).

This highlights the evolving development in fire engineering and the suited application of Alternative Solution to buildings with special uses or unusual features, such as transportation tunnel, underground subway station and skyscraper. These buildings are outside the scope of C/VM2 where the prescribed inputs no longer apply, and additional engineering considerations are required. A few international guidelines including NFPA 101, IFEG and CIBSE Guide E [13-15] provide different levels of details and approaches for fire engineering. At the time of writing, there have been on-going efforts to improve the application of Alternative Solution in New Zealand. For McDougall House, C/VM2 was chosen as the design approach due to the simplified building consent process, given the inherently accepted design fire scenarios, design inputs and minimum performance outcomes.

\section{Application of Verification Method C/VM2 to McDougall House}

$\mathrm{C} / \mathrm{VM} 2$ presents 10 design scenarios that address various fire safety aspects of a building and assess the fire engineering design for the adequacy of means of escape, the performance of active and passive fire protection systems, the ability to limit internal and external fire spread, the provisions to facilitate firefighting and rescue operation, and the redundancy of fire protection systems. The description, performance outcome and compliance solution of each design scenario applicable to the fire engineering design of McDougall House are presented in the following subsections. The fire engineering design comprises quantitative assessments utilizing conventional engineering tools and also qualitative assessments, including benefit versus sacrifice analysis, particularly in relation to cultural heritage aspect.

\subsection{Design Scenario (BE): Fire Blocks Exit}

This design scenario applies to escape routes serving more than 50 people or with a single direction of travel where an escape route may be blocked due to the proximity of fire source. It requires a single means of escape to serve no more than 50 people, with a maximum length of $50 \mathrm{~m}$ if the occupant characteristics are considered as familiar with the building. This is the case for McDougall House with Nurse Maude employees. For up to 250 occupants, to be classified as having two means of escape, the escape routes have to diverge at a minimum $90^{\circ}$ until separated by at least $8 \mathrm{~m}$ apart and remain separated at the final exits. This design scenario is analyzed qualitatively by reviewing the means of escape of McDougall House. The ground floor has 79 occupants served by a minimum of two escape 
routes, which achieve at least $8 \mathrm{~m}$ separation as seen in Figure 4a. On the first floor, 16 occupants are served by a single means of escape via the enclosed stair with a measured travel distance to the fire-rated stair of $23 \mathrm{~m}$, which is less than $50 \mathrm{~m}$. On these bases, the building design satisfies Design Scenario (BE).

\subsection{Design Scenario (UT): Fire in Normally Unoccupied Room Threathening Occupants of Other Rooms}

This design scenario applies to spaces protected by an automatic detection and alarm system containing more than 150 occupants that could be threatened by a fire occurring in another normally unoccupied space such as services plant room and store. The design scenario considers the fire growing to a significant size undetected, spreading to other spaces with a larger occupant load. The design scenario requires adequate means of containment or suppression as solution. This design scenario is analyzed qualitatively by reviewing the fire protection systems of McDougall House. As part of the fire engineering design, McDougall House is protected by automatic smoke detection and alarm system, installed to NZS 4512:2010 [16]. The total occupant load of the building is 95, less than the threshold of 150. Thus, on this basis, the building design satisfies Design Scenario (UT).

\subsection{Design Scenario (CS): Fire Starts in a Concealed Space}

This design scenario applies to spaces containing more than 50 occupants that could be threatened by a fire within the concealed spaces such as roof, ceiling and subfloor cavities containing combustibles or with the smallest dimension exceeding $0.8 \mathrm{~m}$. The design scenario considers the fire developing undetected, spreading to other spaces with larger occupant load. This design scenario requires adequate means of containment, detection or suppression as solution. This design scenario is analyzed qualitatively by reviewing the fire protection systems of McDougall House. As part of the fire engineering design, McDougall House is protected by an automatic fire sprinkler system, installed to NZS 4541:2013 [17]. The sprinkler system coverage includes the roof and ceiling spaces, with the exception of the subfloor space having a depth of no more than $0.8 \mathrm{~m}$ and containing no combustibles. The sprinkler system would detect heat generation and confine the fire to the space of origin. Thus, on this basis, the building design satisfies Design Scenario (CS).

\subsection{Design Scenario (SF): Smouldering Fire}

This design scenario considers a slow smoldering fire threatening the sleeping occupants. As McDougall House is an office and business administration center, it contains no sleeping use. Thus, on this basis, the building design satisfies Design Scenario (SF).

\subsection{Design Scenario (HS): Horizontal Fire Spread}

This design scenario considers a fully developed fire in the building generating high levels of radiation across a relevant boundary onto the external wall of neighboring building or firecell, which could be other property, sleeping occupancy or fire separated escape route, also known as exitway. This design scenario is analyzed quantitatively by reviewing the size of the allowable unprotected areas (UPAs) in the external wall, specifically the new southern entry of McDougall House. External wall areas exceeding the allowable unprotected areas will need to be suitably fire-rated to prevent fire spread across the boundary. The proposed work for the new southern entry into the Ballroom included a new entry located at $1.3 \mathrm{~m}$ from the notional boundary of the adjacent hospital, and a portion of the reconstructed original weatherboard external wall at $2.0 \mathrm{~m}$ set back from the entry. By definition, in NZBC, notional boundary is a boundary that exists between two buildings on the same property under a single land title considered for fire safety and taken as $1.0 \mathrm{~m}$ from the external wall of the building receiving radiation. Figure 5 shows the distance to the adjacent hospital and the elevation of the proposed work for the new southern entry. 


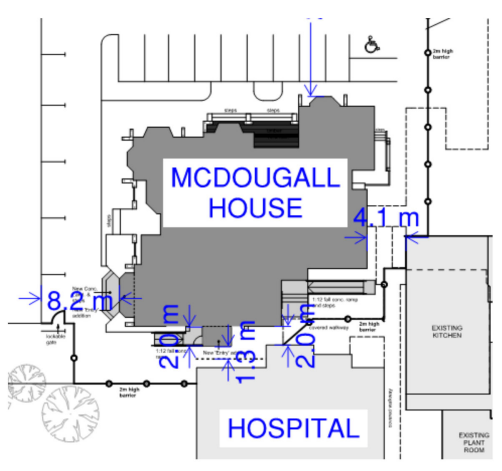

(a)

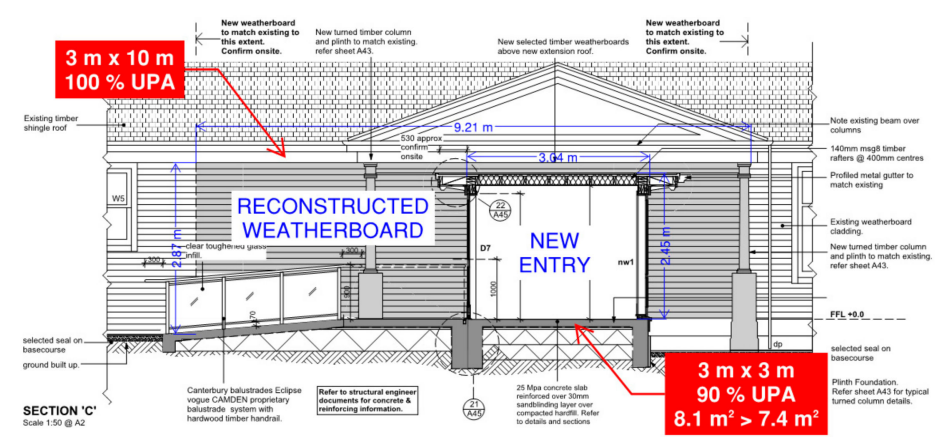

(b)

Figure 5. Quantitative assessment of horizontal fire spread across boundary for the new southern entry of McDougall House: (a) Distance to the adjacent hospital; (b) Proposed work for the new southern entry.

The methodology applied is the tabulated values in C/VM2 Commentary [18], which considers the distance to notional boundary $\left(D_{B}\right)$, the fire load energy density (FLED) based on building use, and the height and width of the unprotected areas $(H$ and $W)$. These parameters determine the maximum allowable unprotected areas to mitigate the risk of horizontal fire spread. Based on information in Figure 5 and for an office occupancy, the parameters evaluated and the maximum allowable unprotected areas for the new entry and the reconstructed wall portion are presented in Table 1.

Table 1. Parameters evaluated and maximum allowable unprotected areas for new southern entry of McDougall House.

\begin{tabular}{ccccc}
\hline External Wall & $\begin{array}{c}\text { Notional } \\
\text { Boundary }\left(\boldsymbol{D}_{\boldsymbol{B}}\right)\end{array}$ & $\begin{array}{c}\text { Fire Load Energy } \\
\text { Density (FLED) } \\
(\mathbf{m})\end{array}$ & $\begin{array}{c}\text { Height and Width of } \\
\text { the Unprotected Areas } \\
(\mathbf{H} \times \boldsymbol{W})(\mathbf{m})\end{array}$ & UPA $^{\mathbf{1}} \mathbf{( \% )}$ \\
\hline New entry & 1.3 & 800 & $3 \times 3$ & 90 \\
Reconstructed wall & 3.3 & 800 & $3 \times 10$ & 100 \\
\hline
\end{tabular}

${ }^{1}$ Doubled allowable unprotected areas (UPAs) due to presence of sprinkler protection.

From the tabulated values, the original allowable UPAs totals $45 \%$ for the new entry and $51 \%$ for the reconstructed wall. With sprinkler protection, these values are doubled as shown in Table 1 as the benefit of installing suppression system. Therefore, the reconstructed wall can remain fully unprotected while further analysis is required for the new entry. The actual size of the new entry is $2.5 \times 3.0 \mathrm{~m}$, giving an area of $7.4 \mathrm{~m}^{2}$. This is less than the actual size of the allowable UPA, which is $90 \%$ of $3.0 \times 3.0 \mathrm{~m}, 8.1 \mathrm{~m}^{2}$. Hence, the new entry can also remain fully unprotected. The remaining external walls of McDougall House have been restored with new paintwork and the replacement of damaged weatherboard. The complete reassessment of the risk of fire spread across boundary for these remaining walls is not deemed necessary as the level of risk which existed originally has not changed following the refurbishment. This is an example of Section 112 provisions, whereby the alterations made have complied with NZBC to at least the same extent as before, resulting in beneficial improvements to the building.

This design scenario is also analyzed qualitatively by reviewing the fire performance of the external wall cladding system in terms of peak heat release rate and total heat released. Different fire performance requirements apply depending on the building height, $D_{B}$ and presence of sprinkler protection. The McDougall House's height is $\geq 7 \mathrm{~m}$ and $\leq 25 \mathrm{~m}$, it is located at more than $1.0 \mathrm{~m}$ away from the boundary and with sprinkler protection, these characteristics result in no requirements for the external wall cladding system. Based on the quantitative and qualitative analyses above, the building design satisfies Design Scenario (HS). 


\subsection{Design Scenario (VS): External Vertical Fire Spread}

This design scenario considers the external vertical fire spread of a multi-story building, affecting the upper floors containing other property, sleeping occupancy or exitway. The fire spread could occur via openings, unprotected areas, an unprotected lower roof or over the façade materials. Where building height exceeds $10 \mathrm{~m}$, the design scenario requires specific fire-rated constructions such as apron and spandrel or the presence of suppression system as solution to fire spread via openings and unprotected areas. It also allows the assessment of the radiation effect from fire plumes projected from these openings to demonstrate limited vertical flame spread of no more than $3.5 \mathrm{~m}$. For a lower roof, the design scenario requires the fire rating to the underside of roof structure or to the higher external wall, or the presence of a suppression system as a solution. Lastly, where building height exceeds $10 \mathrm{~m}$, it also requires adequate fire performance for the external wall cladding system in terms of the peak heat release rate and total heat released, or through a standard façade fire test to ensure no more than a $3.5 \mathrm{~m}$ vertical flame spread above the fire source. This design scenario is analyzed qualitatively by reviewing the building height and fire protection systems of McDougall House. As part of the fire engineering design, McDougall House is protected by an automatic fire sprinkler system and it has a building height of less than $10 \mathrm{~m}$. With the building height remaining below the threshold and sprinkler system being the common solution for most vertical fire spread mechanisms, the building design satisfies Design Scenario (VS).

\subsection{Design Scenario (IS): Rapid Fire Spread Involving Internal Surface Linings}

The design scenario requires the interior surface finishes such as wall and ceiling linings, floorings and suspended flexible fabrics to achieve adequate fire performance according to recognized test standards. This design scenario is analyzed qualitatively by reviewing the fire performance achieved by the new surface finishes and the existing or restored heritage surface finishes. With sprinkler protection, the requirements are lowered as the benefit of installing a suppression system. For the wall and ceiling linings, the fire performance is based on a maximum Group Number (GN) rating attained from standard tests, ISO 5660-1, using small-scale cone calorimeter [19], or ISO 9705, which involves a full-scale room corner test [20]. The rating ranges from GN1 to GN4 with a higher rating corresponding to an increased combustibility of the product. For the fire-rated enclosed stair, which is an exitway, the maximum allowable rating is GN2 while, for other spaces within McDougall House, this is GN3. The proprietary plasterboard linings exposed on walls and ceilings throughout the building do not exceed these maximum rating. For floorings, the fire performance is based on a minimum critical radiant flux for ignition attained from a standard test, ISO 9239-1, using a small-scale radiant panel [21], where a lower heat flux corresponds to an increased ignitability of the product. The minimum heat flux is $2.2 \mathrm{~kW} / \mathrm{m}^{2}$ for the enclosed stair and $1.2 \mathrm{~kW} / \mathrm{m}^{2}$ for the other spaces. The new carpet tiles installed throughout the building exceed these minimum heat fluxes. Through the benefit versus sacrifice analysis, supported by quantitative smoke and egress modelling, the heritage surface finishes, which include the restored ornamental plasterwork ceiling in the Ballroom and numerous existing timber linings throughout, are retained despite having untested fire performance. The benefit versus sacrifice analysis reveals the importance of adhering to the conservation plan by maintaining the originality of heritage surface linings in lieu of the fire-retardant treatment of the materials. Subsequently, quantitative modelling demonstrates that the restored heritage surface finishes do not diminish the level of fire safety, and details of the analysis are presented in Section 4.9. On these bases, the building design satisfies Design Scenario (IS).

\subsection{Design Scenario (FO): Firefighting Operations}

The design scenario requires adequate provisions to facilitate firefighting and rescue operation in a building. This design scenario is analyzed qualitatively by reviewing the fire service vehicular access, means of delivering firefighting water, means of safe access for firefighters, and means of providing 
clear information to identify the fire location, fire protection systems and any hazardous activities within the building. For fire service vehicular access, the requirements are hard standing with an unobstructed path within $20 \mathrm{~m}$ of the building and the fire sprinkler inlets. The external carpark on the northern side of McDougall House, as seen at the top of Figure 5a, provides the hard standing for the vehicle with unobstructed access to the building and the fire sprinkler inlets (FSI) located by the eastern side, which is noted on Figure 4a. For means of delivering firefighting water, the requirements are that the hose run distance from the vehicle does not exceed $75 \mathrm{~m}$ or a building fire hydrant system is installed to NZS 4510:2008 [22]. The measured hose run distance from the vehicle location to any points within McDougall House is no more than $75 \mathrm{~m}$. For means of safe access where the escape height is $\leq 10 \mathrm{~m}$, the requirements are that the hose run distance onto the intermediate floor does not exceed $75 \mathrm{~m}$ and the floor system including its supporting structure have a minimum of $30 \mathrm{~min}$ fire resistance rating. In addition, where the intermediate floor area exceeds $40 \%$ of the total firecell floor area, the floor should be fire-rated for structural adequacy, integrity and insulation. The measured hose run distance onto the intermediate floor complies, and the floor and its load-bearing walls are designed to achieve $30 \mathrm{~min}$ fire resistance rating. For the means of providing clear information, the existing fire alarm panel, which is located in the adjacent hospital, is interfaced with the fire protection system of McDougall House, which includes the analogue addressable smoke detectors, manual call points and sprinkler system. Together, this forms part of the integrated, site-wide fire protection system. On these bases, the building design satisfies Design Scenario (FO).

\subsection{Design Scenario (CF): Challenging Fire}

The design scenario considers a credible worst-case fire starting in a normally occupied space of the building, challenging its fire protection systems and threatening the safety of evacuating occupants. Given sprinkler protection and no possibility of exposing more than 1000 occupants to untenable conditions, the performance outcome is the fractional effective dose of carbon monoxide, FED CO not greater than 0.3 during evacuation, monitored at $2 \mathrm{~m}$ above the floor level. However, this requirement is exempted for the room of fire origin, which meets the following conditions:

1. Room with floor area less than $2 \mathrm{~m}^{2}$.

2. Sanitary facilities adjoining an exitway.

3. Room with a total floor area of less than $500 \mathrm{~m}^{2}$, single direction travel of less than $25 \mathrm{~m}$, and occupant load of less than 150 or 100 for intermediate floor.

4. Room with sleeping care use having no more than four occupants undergoing treatment.

There is no exemption otherwise or for early childhood centers on the upper level and sleeping use with care or detention. A review of McDougall House shows its individual spaces fall under Items 1-3 above, where Item 1 and 2 have already been explicitly addressed by Design Scenario (UT). For Item 3 , which covers majority of the normally occupied spaces, the design scenario requires a tenable condition during evacuation to be maintained for the other spaces within the building. This design scenario is analyzed quantitatively by reviewing the Available Safe Egress Time (ASET) and Required Safe Egress Time (RSET) to demonstrate the safe evacuation of occupants in the event of a fire, RSET < ASET. Throughout McDougall House, five design fires in different locations as shown in Figure 6 are investigated in turn with consideration of their impact on the adjacent spaces:

1. CF1, Design fire in the Main Lobby/Feature Stair: This fire results in smoke spreading into the Ballroom, Corridor and the upper level Passage, which affects egress and challenges the integrity of the smoke separation around the Feature Stair.

2. CF2, Design fire in the Ballroom: This fire results in smoke spreading into the Corridor and Main Lobby/Feature Stair, which affects egress and challenges the external egress past heritage windows of the Ballroom.

3. CF3, Design fire in the Corridor: This fire results in smoke spread into the Ballroom, Main Lobby/Feature Stair and Safe Path Stair, which affects egress. 
4. CF4, Design fire in the Kitchen: This fire results in smoke spreading into the Ballroom and Corridor, which affects egress and challenges the external egress past heritage windows of the Kitchen.

5. CF5, Design fire in the Level 1 Office: This fire results in smoke spreading into the Passage, Main Lobby/Feature Stair and Safe Path Stair, which affects egress.

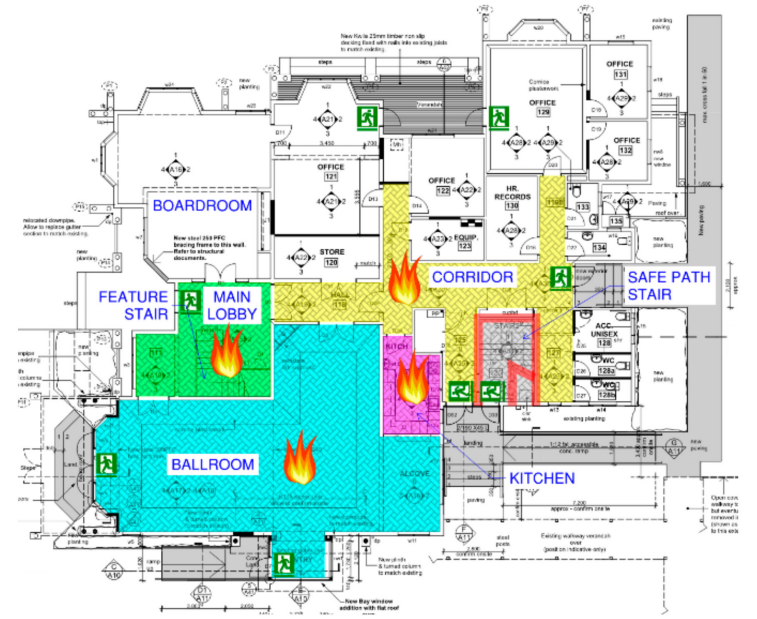

(a)

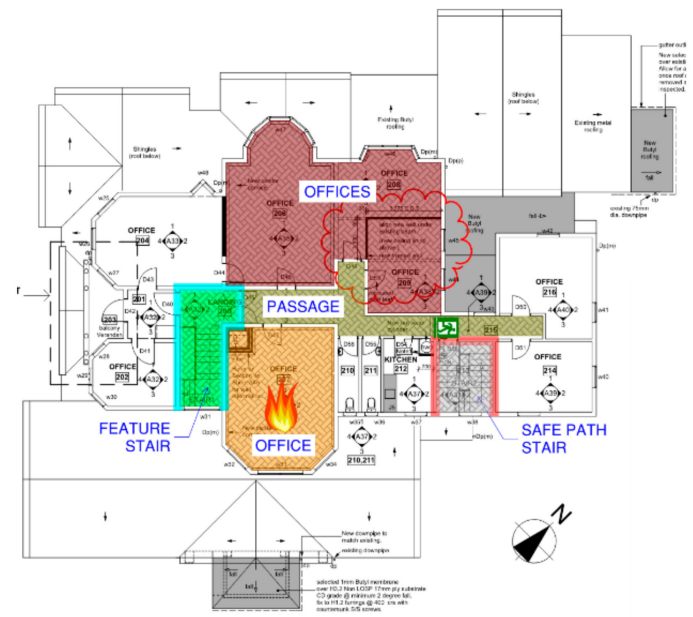

(b)

Figure 6. Design fires and modelled spaces of McDougall House: (a) Ground floor; (b) First floor.

The rooms of fire origin and selected adjacent spaces which are colored in Figure 6 are modelled using B-RISK Version 2019.03 [23], a two-layer zone model for smoke modelling with the inherent assumption that the hot upper layer and the cool lower layer within a compartment is spatially uniform throughout. The validity of this assumption, and thus the applicability of the zone model for the design fire, is dependent on the dimensionless heat release rate, $\dot{Q}^{*}$, and the shape factor, $S F$, of the room of fire origin [24], which are represented by Equations (1) and (2), respectively:

$$
\begin{gathered}
\dot{Q}^{*}=\frac{\dot{Q}}{\rho_{a} c_{p} T_{a} \sqrt{g} H_{e}^{5 / 2}}, \\
S F=\frac{A_{f}}{H_{e}^{2}},
\end{gathered}
$$

where $\rho_{a}=1.2 \mathrm{~kg} / \mathrm{m}^{3}, c_{p}=1.0 \mathrm{~kJ} / \mathrm{kgK}, T_{a}=293 \mathrm{~K}$ and $g=9.81 \mathrm{~m} / \mathrm{s}^{2}$ are constants under ambient conditions, $\dot{Q}$ is the maximum heat release rate within the simulated period, $H_{e}$ is the compartment ceiling height, and $A_{f}$ is the compartment floor area. For $0.4 \leq S F \leq 70$ and $\dot{Q}^{*} \leq 0.15$, a compartment is satisfactorily modelled as a two-layer zone. For $S F>70$ and $\dot{Q}^{*} \leq 0.15$, the original compartment should be represented as multi-compartments where each compartment is $0.4 \leq S F \leq 70$. For $S F<0.4$, the compartment should be modelled as a single layer only, unless it is the room of fire origin which needs to be a two-layer zone. Outside these limits, particularly $\dot{Q}^{*}>0.15$, the design fire should be investigated using a computational fluid dynamics model. Besides $\dot{Q}^{*}$ and $S F$, the aspect ratio or width to length ratio of a compartment is also crucial and this is maintained at no more than 1:5 to ensure model accuracy. This prevents having a single, excessively long compartment, whereby the instantaneous formation of a hot upper layer in a zone model becomes less realistic. The applicability of B-RISK is discussed later in this section for each design fire in conjunction with the respective RSET/ASET analysis.

C/VM2 prescribes different fire growth rates based on the building use and its storage height. For McDougall House, where the storage height is less than $3.0 \mathrm{~m}$, the specified design fire has a 
fast, $t$-squared growth rate. Other characteristics of the design fire including species yields, radiative fraction, etc., are listed in Table 2, which are also B-RISK model inputs. As part of the fire engineering design, McDougall House is protected by an automatic fire sprinkler system and automatic smoke detection and alarm system. The characteristics of a standard response sprinkler head which controls the design fire upon activation and a point type smoke detector as per Table 2 are included as B-RISK model inputs. From Figure 6, some of the spaces are non-rectilinear and these are converted into equivalent volume, rectilinear spaces in B-RISK using Equation (3), which calculates an effective length, $L_{e f f}$, from the perimeter, $P$, and floor area, $A_{f}$, of the space:

$$
L_{e f f}=\frac{P / 2+\sqrt{(P / 2)^{2}-4 A_{f}}}{2},
$$

this allows the effective width to be deduced from the known floor area of the space. Elongated spaces such as the Corridor and upper level Passage are modelled as multi-compartments to limit the aspect ratio to less than 1:5. These spaces are thoroughly open, so full-width and full-height virtual vents are incorporated to ensure a viable pathway for smoke spread. The compartment sizes modelled are listed in Table 2. Realistic and reasonable assumptions on ventilation are vital to the tenability assessment of the simulated spaces. This includes the treatment of internal and external doors, fire and smoke control doors, wall leakages, and the integrity of wall partitions as described in Table 2.

Table 2. Characteristics of the design fire, fire protection system, compartment and ventilation for simulating design fires of Design Scenario (CF).

\begin{tabular}{|c|c|}
\hline Inputs & Characteristics \\
\hline Design fire & $\begin{array}{l}\text { Growth rate: } 0.0469 t^{2} \\
\text { Peak value: } 20 \mathrm{MW} \\
\text { Effective heat of combustion, } \Delta h_{c, \text { eff }}: 20 \mathrm{MJ} / \mathrm{kg} \\
\text { Radiative fraction, } \chi_{r}: 0.35 \\
\text { Fuel composition: } \mathrm{C}_{1} \mathrm{H}_{2} \mathrm{O}_{0.5} \\
\text { Soot yield, } Y_{S}: 0.07 \mathrm{~kg} / \mathrm{kg} \text { (pre-flashover); } 0.14 \mathrm{~kg} / \mathrm{kg} \text { (post-flashover) } \\
\text { Carbon monoxide yield, } Y_{\mathrm{CO}}: 0.04 \mathrm{~kg} / \mathrm{kg} \text { (pre-flashover); } 0.40 \mathrm{~kg} / \mathrm{kg} \text { (post-flashover) } \\
\text { Carbon dioxide yield, } Y_{\mathrm{CO}_{2}}: 1.50 \mathrm{~kg} / \mathrm{kg} \\
\text { Water vapor yield, } Y_{\mathrm{H}_{2} \mathrm{O}}: 0.82 \mathrm{~kg} / \mathrm{kg}\end{array}$ \\
\hline \multirow[t]{2}{*}{$\begin{array}{l}\text { Fire protection } \\
\text { system }\end{array}$} & $\begin{array}{l}\text { Sprinkler: Standard response, controls heat release rate upon activation } \\
\text { Response time index, RTI: } 135 \mathrm{~m}^{1 / 2} \mathrm{~s}^{1 / 2} \\
\text { C-factor: } 0.85 \mathrm{~m}^{1 / 2} \mathrm{~s}^{1 / 2} \\
\text { Activation temperature, } T_{\text {act }}: 68^{\circ} \mathrm{C} \\
\text { Radial distance: } 3.25 \mathrm{~m} \\
\text { Distance below ceiling: } 0.025 \mathrm{~m}\end{array}$ \\
\hline & $\begin{array}{l}\text { Smoke detector: Point type } \\
\text { Optical density at alarm: } 0.097 \mathrm{~m}^{-1} \text {, measured outside chamber } \\
\text { Radial distance: } 7 \mathrm{~m} \\
\text { Distance below ceiling: } 0.025 \mathrm{~m}\end{array}$ \\
\hline Compartment ${ }^{1}$ & $\begin{array}{l}\text { Ballroom: } 16.22-5.77-3.43 \mathrm{~m} ; S F=8.0 \\
\text { Kitchen: } 5.09-2.18-3.43 \mathrm{~m} ; S F=0.9 \\
\text { Level } 1 \text { Office: } 5.48-5.42-3.00 \mathrm{~m} ; S F=3.3 \\
\text { Level } 1 \text { Offices: } 15.57-4.12-3.00 \mathrm{~m} ; S F=7.1 \\
\text { Corridor: } 8.12-1.65-3.43 \mathrm{~m} \text { (four connected compartments); } S F=1.1 \\
\text { Level } 1 \text { Passage: } 5.38-1.14-3.00 \mathrm{~m} \text { (three connected compartments); } S F=0.7 \\
\text { Main Lobby/Feature Stair: } 5.36-1.94-7.14 \mathrm{~m} ; S F=0.2 \\
\text { Safe Path Stair: } 3.24-2.60-7.14 \mathrm{~m} ; S F=0.2\end{array}$ \\
\hline Ventilation & $\begin{array}{l}\text { Internal doors: } \\
\text { Non-fire-rated door considered open at all times } \\
\text { Fire and/or smoke control door with self-closer considered open during egress only }\end{array}$ \\
\hline
\end{tabular}


Table 2. Cont.

\begin{tabular}{ll}
\hline \multicolumn{1}{c}{ Inputs } & Characteristics \\
\hline \multirow{3}{*}{ Ventilation } & External doors: \\
& Closed at all times \\
\cline { 2 - 2 } & Door leakage: \\
\cline { 2 - 2 } & 10-mm gap under fire and/or smoke control door \\
& Wall leakage: \\
& Fire- and/or smoke-rated wall has no leakage \\
& $0.1 \%$ leakage area for lined internal and external walls \\
\cline { 2 - 2 } & Integrity of wall partitions: \\
& Non-fire-rated and smoke-rated walls to fail at $200{ }^{\circ} \mathrm{C}$ \\
\hline
\end{tabular}

${ }^{1}$ Compartment geometry presented as length-width-height for a single room, number of multi-rooms will be indicated in brackets.

Smoke modelling using B-RISK evaluates the tenability of the spaces modelled based on time when FED CO $_{\text {reaches }} 0.3$ or ASET. The other part of the RSET/ASET analysis is the evacuation modelling which determines the evacuation time, RSET, represented by Equation (4) as a function of detection, notification, pre-movement and egress times:

$$
\mathrm{RSET}=t_{\text {det }}+t_{\text {not }}+t_{\text {pre }}+t_{\text {egr }}
$$

the RSET/ASET analysis requires interchanging information between the smoke model and evacuation model. RSET requires detection time, $t_{\text {det }}$, attained from the smoke model, while for ASET, the door opening and closing time during egress as part of B-RISK ventilation input is determined from the evacuation calculation. McDougall House adopts a standard all-out evacuation strategy. Thus, the notification time, $t_{n o t}$, is $30 \mathrm{~s}$. Based on the building use as an office and business administration center and the occupants who are Nurse Maude employees, who are awake, alert and familiar with the building, their pre-movement time, $t_{\text {pre }}$, are $30 \mathrm{~s}$ for the room of fire origin and $60 \mathrm{~s}$ for the adjacent spaces. Egress time, $t_{\text {egr }}$, is governed either by the walking speed, $S$, and travel distance in an uncongested scenario, or the flow rate through constriction, $F_{c}$, and occupant load when queuing occurs, whichever is the longer duration. Applying the first order hydraulic calculation [25], Equations (5) and (6) solve $S$ and $F_{c}$, respectively:

$$
\begin{gathered}
S=k-a k D, \\
F_{c}=(1-a D) k D W_{e},
\end{gathered}
$$

The constants and maximum values associated with the determination of $S$ and $F_{c}$ are summarized in Table 3.

Table 3. Constants and maximum values for walking speed and flow rate calculation.

\begin{tabular}{cl}
\hline Parameters & Values \\
\hline$k$ & $\begin{array}{l}1.4 \text { for horizontal travel } \\
1.0 \text { for vertical travel }\end{array}$ \\
\hline$a$ & 0.266 \\
\hline$D$ & $\begin{array}{l}\text { Calculated occupant density of the specific space, } \mathrm{P} / \mathrm{m}^{2} \text { for } S \text { calculation } \\
\text { Assumed occupant density at constriction point, } 1.9 \mathrm{P} / \mathrm{m}^{2} \text { for } F_{c} \text { calculation }\end{array}$ \\
\hline \multirow{2}{*}{$W_{e}$} & $\begin{array}{l}\text { Effective width of constriction, which is the original clear width minus the } 0.15-\mathrm{m} \\
\text { boundary layer on each side of door and stair }\end{array}$ \\
\hline \multirow{2}{*}{$S_{\max }$} & $\begin{array}{l}\text { Maximum horizontal walking speed, } 1.20 \mathrm{~m} / \mathrm{s} \\
\text { Maximum vertical walking speed, } 0.85 \mathrm{~m} / \mathrm{s}\end{array}$ \\
\hline \multirow{2}{*}{$F_{c, \max }$} & $\begin{array}{l}\text { Maximum flow rate for door with self-closer, } 50 \mathrm{P} / \mathrm{min} / \mathrm{leaf} \\
\text { No maximum limit for door without self-closer }\end{array}$ \\
\hline
\end{tabular}


The outcomes from smoke and evacuation modelling enable the assessment of RSET and ASET for the five design fires proposed. The details of the unfolding chronological events from smoke modelling and the RSET/ASET analysis performed are presented in Table 4.

Table 4. Required Safe Egress Time (RSET)/Available Safe Egress Time (ASET) analysis for design fires of Design Scenario (CF).

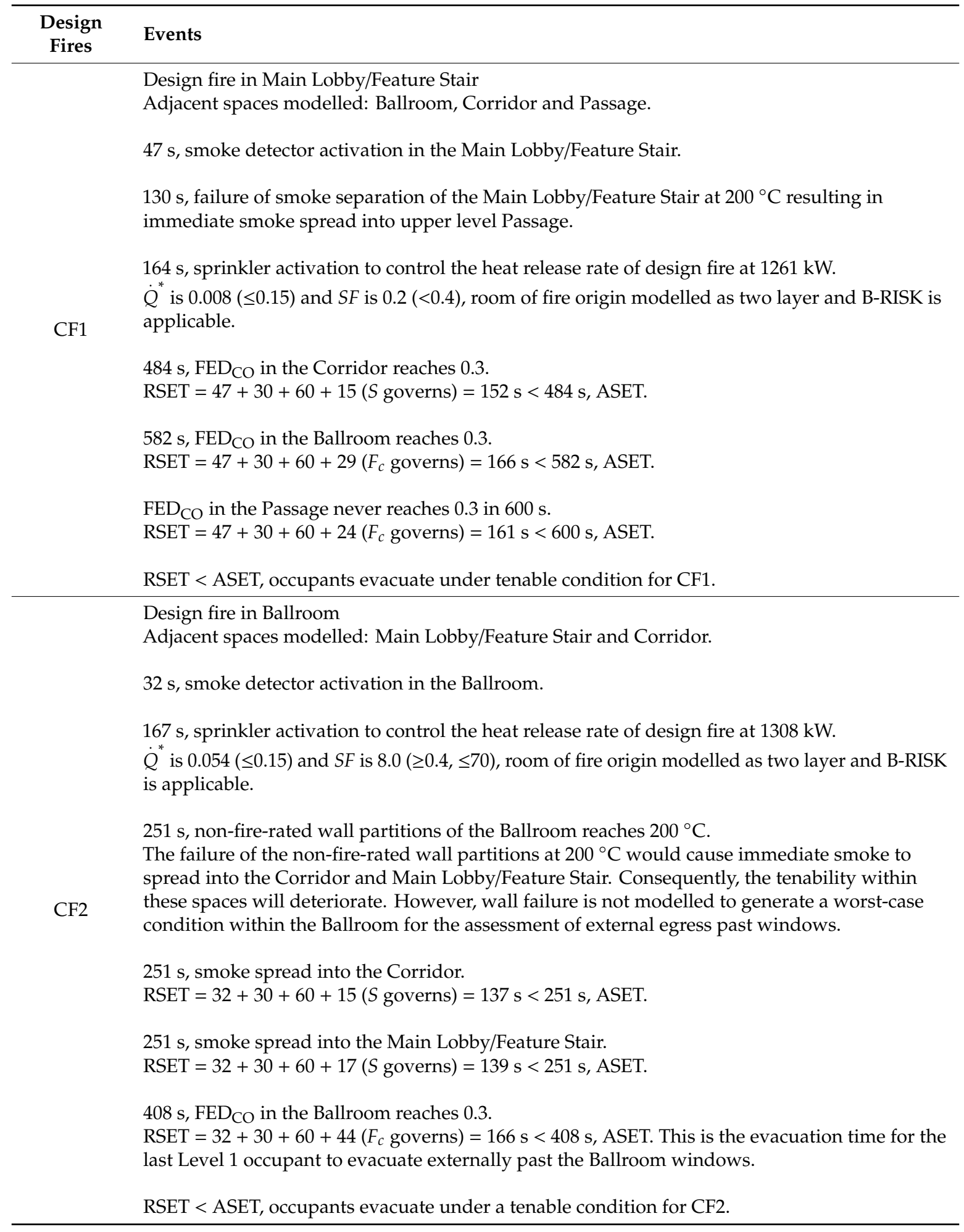


Table 4. Cont.

\begin{tabular}{|c|c|}
\hline $\begin{array}{l}\text { Design } \\
\text { Fires }\end{array}$ & Events \\
\hline \multirow{18}{*}{ CF3 } & Design fire in Corridor \\
\hline & Adjacent spaces modelled: Main Lobby/Feature Stair, Safe Path Stair and Ballroom. \\
\hline & $35 \mathrm{~s}$, smoke detector activation in the Corridor. \\
\hline & $151 \mathrm{~s}$, sprinkler activation to control the heat release rate of design fire at $1069 \mathrm{~kW}$. \\
\hline & $\begin{array}{l}\dot{Q}^{*} \text { is } 0.044(\leq 0.15) \text { and } S F \text { is } 0.9(\geq 0.4, \leq 70) \text {, room of fire origin modelled as two layer and B-RISK } \\
\text { is applicable. }\end{array}$ \\
\hline & $166 \mathrm{~s}$, non-fire-rated wall partitions of the Corridor reaches $200^{\circ} \mathrm{C}$. \\
\hline & The failure of the non-fire-rated wall partitions at $200{ }^{\circ} \mathrm{C}$ would cause immediate smoke to \\
\hline & spread into the Ballroom and Main Lobby/Feature Stair, and also other adjacent spaces which are \\
\hline & not modelled. Consequently, the tenability within these spaces will deteriorate. However, wall \\
\hline & failure is not modelled to generate a worst-case condition for smoke spread into the Safe Path \\
\hline & Stair. \\
\hline & 166 s, smoke spread into the Main Lobby/Feature Stair. \\
\hline & RSET $=35+30+60+17(S$ governs $)=142 \mathrm{~s}<166 \mathrm{~s}$, ASET. \\
\hline & $166 \mathrm{~s}$, smoke spread into the Ballroom. \\
\hline & RSET $=35+30+60+29\left(F_{c}\right.$ governs $)=154 \mathrm{~s}<166 \mathrm{~s}$, ASET. \\
\hline & FED $_{\mathrm{CO}}$ in the Safe Path Stair never reaches 0.3 in $600 \mathrm{~s}$. \\
\hline & RSET $=35+30+60+40\left(F_{c}\right.$ governs $)=165 \mathrm{~s}<600 \mathrm{~s}$, ASET \\
\hline & RSET $<$ ASET, occupants evacuate under a tenable condition for CF3. \\
\hline
\end{tabular}

Design fire in Kitchen

Adjacent spaces modelled: Ballroom and Corridor.

$54 \mathrm{~s}$, smoke detector activation in the Corridor.

Smoke detector is not installed within the Kitchen due to risk of false alarm.

$95 \mathrm{~s}$, failure of non-fire-rated wall partitions of the Kitchen at $200{ }^{\circ} \mathrm{C}$ resulting in immediate smoke spread into the Ballroom and Corridor.

$156 \mathrm{~s}$, sprinkler activation to control the heat release rate of design fire at $1141 \mathrm{~kW}$.

$\dot{Q}^{*}$ is $0.047(\leq 0.15)$ and $S F$ is $0.9(\geq 0.4, \leq 70)$, room of fire origin modelled as two layer and B-RISK is applicable.

$227 \mathrm{~s}$, fire becomes ventilation limited.

CF4 This requires the failure of the Kitchen window to maintain the capped heat release rate. However, window failure is not modelled to prevent smoke outflow and to generate a worst-case condition within the Kitchen for the assessment of external egress past window.

$317 \mathrm{~s}, \mathrm{FED}_{\mathrm{CO}}$ in the Kitchen reaches 0.3.

RSET $=54+30+60+44\left(F_{c}\right.$ governs $)=188 \mathrm{~s}<317 \mathrm{~s}$, ASET. This is the evacuation time for the last Level 1 occupant to evacuate externally past the Kitchen window.

$328 \mathrm{~s}, \mathrm{FED}_{\mathrm{CO}}$ in the Corridor reaches 0.3 .

RSET $=54+30+60+15(S$ governs $)=159 \mathrm{~s}<328 \mathrm{~s}$, ASET.

$333 \mathrm{~s}, \mathrm{FED}_{\mathrm{CO}}$ in the Ballroom reaches 0.3.

RSET $=54+30+60+29\left(F_{c}\right.$ governs $)=173 \mathrm{~s}<333 \mathrm{~s}$, ASET.

RSET < ASET, occupants evacuate under a tenable condition for CF4. 
Table 4. Cont.

\begin{tabular}{|c|c|}
\hline $\begin{array}{c}\text { Design } \\
\text { Fires }\end{array}$ & Events \\
\hline \multirow{23}{*}{ CF5 } & Design fire in Level 1 Office \\
\hline & Adjacent spaces modelled: Passage, Main Lobby/Feature Stair, Safe Path Stair and Level 1 Offices. \\
\hline & $31 \mathrm{~s}$, smoke detector activation in the Level 1 Office. \\
\hline & $113 \mathrm{~s}$, failure of non-fire-rated wall partitions of the Level 1 Office at $200{ }^{\circ} \mathrm{C}$, resulting in \\
\hline & immediate smoke to spread into the Passage and Main Lobby/Feature Stair. \\
\hline & $121 \mathrm{~s}$, fire and smoke control door into the Safe Path Stair is opened for egress allowing the \\
\hline & ingress of smoke from the Passage. \\
\hline & $137 \mathrm{~s}$, sprinkler activation to control the heat release rate of design fire at $880 \mathrm{~kW}$. \\
\hline & $\dot{Q}^{*}$ is $0.051(\leq 0.15)$ and $S F$ is $3.3(\geq 0.4, \leq 70)$, room of fire origin modelled as two layer and \\
\hline & B-RISK is applicable. \\
\hline & $145 \mathrm{~s}$, fire and smoke control door into the Safe Path Stair, which is closed as the last Level 1 \\
\hline & occupant evacuates. \\
\hline & $155 \mathrm{~s}$, fire becomes ventilation limited. \\
\hline & This requires the failure of the Level 1 Office window to maintain the capped heat release rate. \\
\hline & However, window failure is not modelled to prevent smoke outflow, which will alleviate the \\
\hline & tenability within the modelled compartments. \\
\hline & $331 \mathrm{~s}, \mathrm{FED}_{\mathrm{CO}}$ in the Passage reaches 0.3. \\
\hline & RSET $=31+30+60+24\left(F_{c}\right.$ governs $)=145 \mathrm{~s}<331 \mathrm{~s}$, ASET \\
\hline & 337 s, FED $\mathrm{CO}$ in the Main Lobby/Feature Stair reaches 0.3. \\
\hline & $\mathrm{RSET}=31+30+60+17(S$ governs $)=138 \mathrm{~s}<337 \mathrm{~s}$, ASET \\
\hline & FED $_{\mathrm{CO}}$ in the Safe Path Stair never reaches 0.3 in $600 \mathrm{~s}$. \\
\hline & $\mathrm{RSET}=31+30+60+40\left(F_{c}\right.$ governs $)=161 \mathrm{~s}<600 \mathrm{~s}$, ASET \\
\hline & RSET $<$ ASET, occupants evacuate under a tenable condition for CF5. \\
\hline
\end{tabular}

The ventilation characteristics described in Table 2 promote internal smoke spread to adjacent spaces modelled and reduce smoke outflow to outside with the aim of generating a worst-case condition within the simulated compartments. These include treating external doors and any internal doors to spaces excluded from the model as closed, simulating under door leakage for normally closed fire and/or smoke control doors, treating internal non-fire-rated doors between modelled spaces as open at all times, and simulating wall leakage between compartments. From Table 4, certain ventilation characteristics are not simulated such as the failure of exterior windows and non-fire-rated wall partitions. The intention is to generate worst-case FED $_{\mathrm{CO}}$ for a specific space or scenario of interest. For instance, to investigate the tenability of external egress past windows, one of the requirements is to maintain a tenable condition within the room of fire origin when the last occupant evacuates externally past its windows. Therefore, in CF2 and CF4, the failure of non-fire-rated wall partitions of the Ballroom and exterior window of the Kitchen have not been simulated to prevent smoke outflow, ensuring worst-case condition for these rooms of fire origin. In order to challenge the egress via the Safe Path Stair, similarly in CF3, the failure of the non-fire-rated partition of the Corridor has not been simulated to channel more smoke flow into the stair.

Ventilation modelling depends on the provided guidelines and mandated performance outcomes from the building code, and also the interpretation of the designer to achieve a conservative RSET/ASET analysis. Changes in ventilation have a varying impact on the performance outcomes, and often, 
sensitivity analysis is performed to understand the extent of such impact. For CF5, the effect from the failure to one of the windowpane is investigated. At ventilation limit, a $1.20 \mathrm{~m}$ by $2.08-\mathrm{m}$ window is simulated to fail, which maintains the fire's capped heat release rate throughout as seen in Figure 7 when compared with the scenario where the window stays in place. Due to the sustained heat release rate, a higher upper layer temperature within the simulated compartments is achieved in the simulation with window failure, as seen in Figure 8.

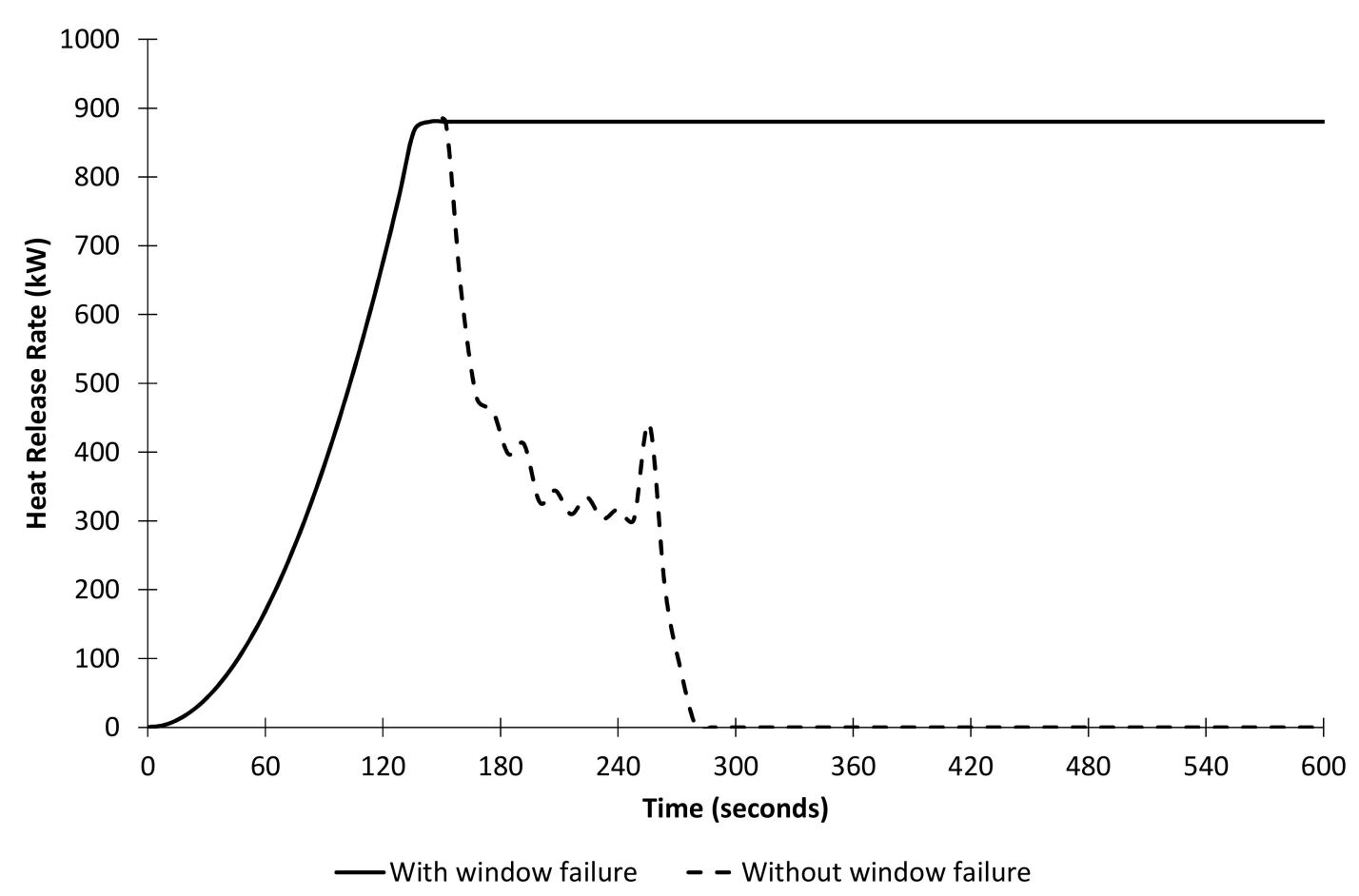

Figure 7. Heat release rate of CF5 with and without window failure.

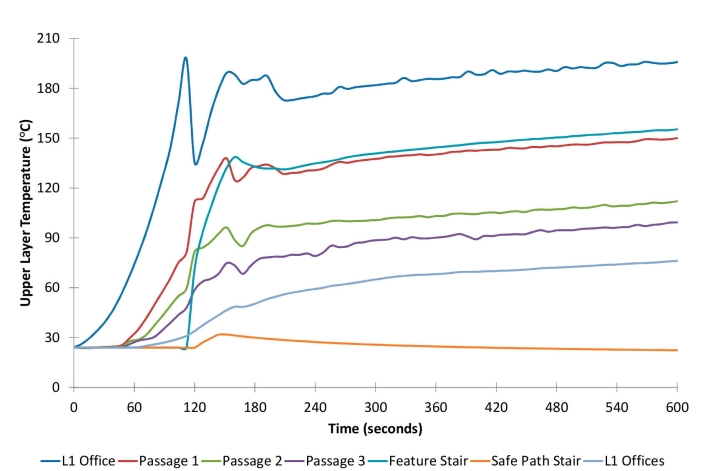

(a)

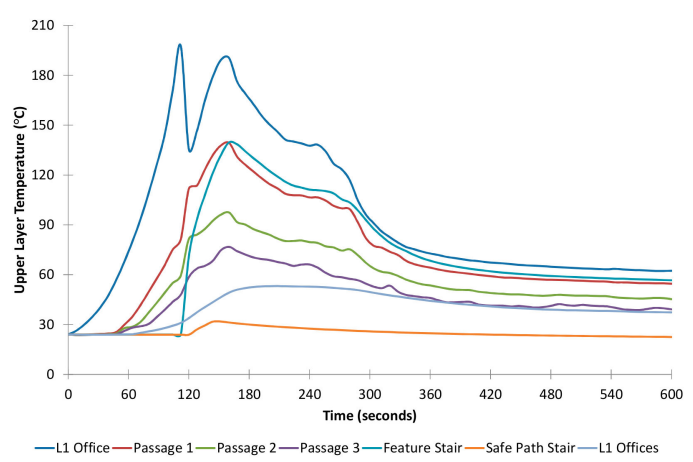

(b)

Figure 8. Upper layer temperature for compartments of CF5: (a) With window failure; (b) Without window failure.

The higher upper layer temperature generates more severe thermal radiation on the egressing occupants in terms of the fractional effective dose of thermal effects, $\mathrm{FED}_{\text {therm. }}$. Table 5 compares the time to $\mathrm{FED}_{\mathrm{CO}}$ and $\mathrm{FED}_{\text {therm, }}$ reaching 0.3 for $\mathrm{CF} 5$ with and without failure of the window. The comparison shows the impact of increased ventilation from the failed window, notably causing FED $_{\text {therm }}$ within the Passage to exceed 0.3 which otherwise would not have occurred. Consequently, the outflow of smoke through the failed window greatly improves the tenability in terms of $\mathrm{FED}_{\mathrm{CO}}$ for the adjacent spaces. Lastly, given $\mathrm{C} / \mathrm{VM} 2$ requirements that $\mathrm{FED}_{\mathrm{CO}}$ is the only performance criterion assessed for 
building with sprinkler protection and with no possibility of exposing more than 1000 occupants to untenable conditions, the scenario without a failed window is more conservative for McDougall House. However, for the scenario with over 1000 exposed occupants, the changes in ventilation might trigger a more onerous tenability condition in relation to the thermal effects as demonstrated.

Table 5. Time of FED $\mathrm{CO}_{\text {and }} \mathrm{FED}_{\text {therm }}$ reaching 0.3 (in seconds) for modelled spaces of CF5 with and without window failure.

\begin{tabular}{cccc}
\hline Scenario & Compartment & FED $_{\text {CO }}=\mathbf{0 . 3}$ & FED $_{\text {therm }} \mathbf{= 0 . 3}$ \\
\hline & Level 1 Office & 549 & 110 \\
& Level 1 Offices & $>600$ & $>600$ \\
With window failure & Passage 1 & $>600$ & 176 \\
& Passage 2 & $>600$ & 282 \\
& Passage 3 & $>600$ & 388 \\
& Main Lobby/Feature Stair & $>600$ & 188 \\
& Safe Path Stair & $>600$ & $>600$ \\
\hline \multirow{5}{*}{ Without window failure } & Level 1 Office & 296 & 110 \\
& Level 1 Offices & 508 & $>600$ \\
& Passage 1 & 331 & 172 \\
& Passage 2 & 389 & $>600$ \\
& Passage 3 & 454 & 187 \\
& Main Lobby/Feature Stair & 337 & $>600$ \\
\hline
\end{tabular}

The outcomes of the quantitative RSET/ASET analysis are also utilized in a qualitative manner to assess a few other aspects of the building design, particularly those relating to cultural heritage, which comply with NZBC under ANARP basis. As per C/VM2 requirement, the fire resistance rating of the Safe Path Stair is designed to be greater than at least three times the longest evacuation time of the building. According to Table 4, this is $188 \mathrm{~s}$ for the evacuation past the Kitchen window, so the minimum fire resistance rating is $10 \mathrm{~min}$. Based on available proprietary fire-rated wall systems, the $30 \mathrm{~min}$ fire-rated plasterboard wall system utilizing the existing lath substrate is specified for the Safe Path Stair. As mentioned in Section 2, the original lath and plaster walls were extensively damaged where some were required to be fire-rated to support the upper level. The damaged walls were replaced by (1) proprietary fire-rated plasterboard wall systems with new timber frame, (2) new plasterboards on the existing lath substrate or (3) a composite wall of heritage timber panels on lath and plaster with mineral wool in cavity on one side and a new plasterboard wall on the other. The first type of wall systems is a tested solution, while the latter two are specified after consultation with the manufacturer, who advised that these can achieve an equivalent performance as the available fire-rated plasterboard wall systems.

The conservation plan of McDougall House aims to restore the heritage interior surface finishes without further fire-retardant treatment, which if applied can have an adverse effect on the materials' appearance due to product compatibility and might not be a cost-effective solution. The ornamental plasterwork ceiling in the Ballroom has been restored with repair to the cracks and the installation of concealed sprinkler pipework and heads above the ceiling. The ceiling was also slightly lowered to accommodate the $30 \mathrm{~min}$ fire-rated plasterboard floor system above. The original heritage timber skirting, paneling, trims, etc., have also been restored throughout the building. In order to retain these heritage surface linings with unknown fire performance, the fire engineering design assumes a fire starting on the heritage surface linings would have equivalent severity as the design fires specified. Although not required under Design Scenario (CF), RSET/ASET analysis is carried out for the room of fire origin to demonstrate fire starting on the heritage surface linings will not result in untenable condition for the egressing occupants. Table 6 shows the RSET/ASET analysis for the room of fire origin of the design fires proposed. 
Table 6. RSET/ASET analysis for room of fire origin containing heritage surface linings.

\begin{tabular}{cccc}
\hline Design Fires & Room of Fire Origin & RSET & ASET (FED CO $=0.3$ ) \\
\hline CF1 & Main Lobby/Feature Stair & 154 & 419 \\
CF2 & Ballroom & 151 & 408 \\
CF3 & Corridor & 140 & 392 \\
CF4 & Kitchen & 147 & 317 \\
CF5 & Level 1 Office & 127 & 296 \\
\hline
\end{tabular}

As RSET < ASET, the occupants can evacuate the room of fire origin under tenable conditions from a fire starting on the heritage surface lining. This is primarily due to the early warning provided by the new smoke detection system, which initiates the evacuation at an earlier time. The results of CF2 and CF4 in Table 4 have demonstrated safe external egress past the Ballroom and Kitchen windows and, as an added level of safety, the fire engineering design has incorporated quick response sprinkler heads local to these windows to provide a more rapid response in the event of a fire. Based on the quantitative and qualitative analyses above, the building design satisfies Design Scenario (CF).

\subsection{Design Scenario (RC): Robustness Check}

This design scenario applies to spaces containing more than 150 people where the failure of a key fire safety system could expose the occupants to untenable conditions during fire. The design scenario considers the sequential failure of any fire protection and fire safety features, which relies on a mechanical or electronic component to be activated during fire. These include an automatic smoke control system, fire and smoke control door, curtain and other similar closures. However, an exemption applies to fire sprinkler systems and automatic fire alarm systems installed to recognized standards. Also, in a sprinkler-protected building, an exemption applies to the fire and smoke control doors equipped with an electromagnetic hold-open device installed to recognized standards which can be activated by the fire alarm system to close these doors. This design scenario is analyzed qualitatively by reviewing the fire protection systems of McDougall House. As part of the fire engineering design, McDougall House is protected by the sprinkler system installed to NZS 4541:2013 and considered to be sufficiently reliable, and the fire and smoke control doors are equipped with electromagnetic hold-open devices connected to the fire alarm. The total occupant load of the building is 95, less than the threshold of 150, and there are no other key fire safety systems identified. Thus, on these bases, the building design satisfies Design Scenario (RC).

\section{Upgrades to the Fire Safety and Fire Protection Systems of McDougall House}

The application of C/VM2, coupled with ANARP considerations for the heritage fabrics has enabled the refurbishment of McDougall House, both externally and internally, to be carried out according to the conservation plan. As a result, the majority of the cultural heritage values are retained such as the exterior architectural design and the interior ornamental timber and plasterwork linings. The performance-based fire engineering design results in an upgrade to the fire safety and fire protection systems of the building, and Table 7 compares the existing and upgraded conditions.

In summary, the performance-based fire engineering design improves the level of fire safety of the building and enhances its heritage value with a new smoke detection system, heritage sympathetic fire protection systems, e.g., concealed sprinkler pipework and heads, and new fire-rated floors and walls completed with compatible fire-stopping products. Both qualitative and quantitative analyses are required in ensuring that the fire engineering design is compliant with NZBC and also satisfies the heritage conservation requirements. 
Table 7. Existing and upgraded conditions of the fire safety and fire protection systems of McDougall House.

\begin{tabular}{|c|c|c|}
\hline $\begin{array}{c}\text { Fire } \\
\text { Safety/Protection } \\
\text { Systems }\end{array}$ & Existing & Upgraded \\
\hline \multirow{3}{*}{$\begin{array}{l}\text { Automatic fire } \\
\text { sprinkler system }\end{array}$} & $\begin{array}{l}\text { Exposed sprinkler pipework under } \\
\text { ceiling. }\end{array}$ & $\begin{array}{l}\text { Concealed sprinkler pipework above } \\
\text { ceiling, particularly for the ornamental } \\
\text { plasterwork ceiling of Ballroom. }\end{array}$ \\
\hline & $\begin{array}{l}\text { Combination of outdated brass pendant } \\
\text { sprinkler heads and standard response } \\
\text { sprinkler heads. }\end{array}$ & $\begin{array}{l}\text { Combination of standard and quick } \\
\text { response sprinkler heads with concealed } \\
\text { type installed within the Ballroom, Main } \\
\text { Lobby and Boardroom. }\end{array}$ \\
\hline & Exposed fire hose reel mounted on wall. & $\begin{array}{l}\text { Fire hose reel located within recessed } \\
\text { cabinet on the wall. }\end{array}$ \\
\hline \multirow[t]{2}{*}{ Fire alarm system } & $\begin{array}{l}\text { Manual alarm system with } \\
\text { supplementary smoke detection. }\end{array}$ & $\begin{array}{l}\text { Automatic analogue addressable smoke } \\
\text { detection system with manual call points. }\end{array}$ \\
\hline & Outdated bell-type sounder. & $\begin{array}{l}\text { Electronic sounder with compliant alarm } \\
\text { signature. }\end{array}$ \\
\hline \multirow{3}{*}{$\begin{array}{l}\text { Fire and/or smoke } \\
\quad \text { control door }\end{array}$} & $\begin{array}{l}\text { Absence of fire and smoke control doors } \\
\text { within the designated fire and smoke } \\
\text { separations of the fire-rated Safe Path } \\
\text { Stair. }\end{array}$ & $\begin{array}{l}\text { Fire and smoke control doors }-/ 30 / 30 \mathrm{sm} \\
\text { rating leading into the fire-rated Safe Path } \\
\text { Stair at ground and first floors. }\end{array}$ \\
\hline & $\begin{array}{l}\text { Absence of smoke control doors within } \\
\text { the designated smoke separations at first } \\
\text { floor of the Feature Stair. }\end{array}$ & $\begin{array}{l}\text { Smoke control doors -/-/- sm rating within } \\
\text { the first-floor smoke separation of the } \\
\text { Feature Stair. }\end{array}$ \\
\hline & $\begin{array}{l}\text { Absence of smoke seals, door closers, } \\
\text { electromagnetic hold-open devices and } \\
\text { certified door tags for the fire and/or } \\
\text { smoke control doors. }\end{array}$ & $\begin{array}{l}\text { Fire and/or smoke control doors equipped } \\
\text { with smoke seals, door closers, } \\
\text { electromagnetic hold-open devices and } \\
\text { certified door tags. }\end{array}$ \\
\hline \multirow{6}{*}{$\begin{array}{l}\text { Fire- and } \\
\text { smoke-rated } \\
\text { construction }\end{array}$} & \multirow{3}{*}{$\begin{array}{l}\text { No fire rating to the first floor and its } \\
\text { load-bearing walls and structural steel } \\
\text { elements due to earthquake damage to } \\
\text { the floor and wall linings. }\end{array}$} & $\begin{array}{l}\text { Fire-rated plasterboard timber joist floor } \\
\text { and ceiling system, achieving } 30 \mathrm{~min} \text { fire } \\
\text { rating for exposure from the underside. }\end{array}$ \\
\hline & & $\begin{array}{l}\text { Fire-rated plasterboard wall system } \\
\text { utilizing an existing lath substrate or new } \\
\text { timber frame, or a composite wall, } \\
\text { achieving } 30 \text { min fire rating with fire } \\
\text { exposure from all sides. }\end{array}$ \\
\hline & & $\begin{array}{l}\text { Fire-rated plasterboard timber-framed } \\
\text { system encapsulating structural steel } \\
\text { elements, achieving } 30 \text { min fire rating with } \\
\text { fire exposure from all sides. }\end{array}$ \\
\hline & \multirow{2}{*}{$\begin{array}{l}\text { No fire rating to the fire-rated Safe Path } \\
\text { Stair and storage cupboard under stair } \\
\text { due to earthquake damage to its wall } \\
\text { linings. }\end{array}$} & $\begin{array}{l}\text { Fire-rated plasterboard timber-framed } \\
\text { ceiling system to underside of stair, } \\
\text { achieving } 30 \text { min fire rating for exposure } \\
\text { from the underside. }\end{array}$ \\
\hline & & $\begin{array}{l}\text { Fire-rated plasterboard wall system } \\
\text { utilizing an existing lath substrate, } \\
\text { achieving } 30 \text { min fire rating for exposure } \\
\text { from either side. }\end{array}$ \\
\hline & $\begin{array}{l}\text { No fire rating to the existing chimney } \\
\text { voids due to the removal of chimneys } \\
\text { following earthquake damage. }\end{array}$ & $\begin{array}{l}\text { Fire-rated plasterboard timber-framed shaft } \\
\text { system, achieving } 30 \text { min fire rating for } \\
\text { exposure from either side. }\end{array}$ \\
\hline
\end{tabular}


Table 7. Cont.

\begin{tabular}{cll}
$\begin{array}{c}\text { Fire } \\
\begin{array}{c}\text { Safety/Protection } \\
\text { Systems }\end{array}\end{array}$ & \multicolumn{1}{c}{ Existing } & \multicolumn{1}{c}{ Upgraded } \\
\hline $\begin{array}{c}\text { Fire- and } \\
\text { smoke-rated } \\
\text { construction }\end{array}$ & $\begin{array}{l}\text { No fire-stopping service penetrations } \\
\text { through fire-rated floor and walls. }\end{array}$ & $\begin{array}{l}\text { Proprietary fire-stopping products } \\
\text { including fire-rated collars and wraps, } \\
\text { fire-rated intumescent mastic, fire-rated } \\
\text { mineral batts, etc., installed to maintain the } \\
\text { fire rating of the floor and walls. }\end{array}$ \\
\hline $\begin{array}{c}\text { Emergency } \\
\text { lighting and exit } \\
\text { signage }\end{array}$ & $\begin{array}{l}\text { Outdated emergency lighting model with } \\
\text { limited coverage (no coverage where } \\
\text { there is a change in level, e.g., Feature } \\
\text { Stair and external ramps), not complying } \\
\text { with NZBC requirements. }\end{array}$ & $\begin{array}{l}\text { Emergency lighting coverage, design and } \\
\text { construction details meeting NZBC } \\
\text { requirements. }\end{array}$ \\
\cline { 2 - 3 } & $\begin{array}{l}\text { Combination of illuminated exit signage } \\
\text { and outdated non-illuminated exit } \\
\text { signage, not complying with NZBC } \\
\text { requirements. }\end{array}$ & $\begin{array}{l}\text { Illuminated exit signage coverage, design } \\
\text { and construction details meeting NZBC } \\
\text { requirements. }\end{array}$ \\
\hline
\end{tabular}

Author Contributions: Conceptualization, D.P., C.D. and C.F.; methodology, D.P. and C.D.; software, D.P.; validation, D.P., C.D. and C.F.; formal analysis, D.P.; investigation, D.P.; resources, D.P.; data curation, D.P.; writing-original draft preparation, D.P.; writing—-review and editing, D.P., C.D. and C.F.; visualization, D.P.; supervision, C.D. and C.F.; project administration, D.P.

Funding: This research received no external funding.

Acknowledgments: The authors would like to acknowledge Murray Hendy (Nurse Maude Association), Brady Cosgrove and Mark Taylor (Cosgroves Ltd.), William Fulton (Fulton Ross Team Architects), Stephen Barrow (Lewis and Barrow Ltd.), Daryl Partridge (Trengrove Architects Ltd.), Armitage Williams Construction and Alexander Turnbull Library for the contribution to project information.

Conflicts of Interest: The authors declare no conflict of interest.

\section{References}

1. ICOMOS. New Zealand Charter for the Conservation of Places of Cultural Heritage Value; ICOMOS NZ (Inc.): Auckland, New Zealand, 2010.

2. Duncan, C.R.; Whiting, P.; Wade, C.A.; Whiting, D.; Henderson, A. Fire Protection of New Zealand's Traditional Māori Buildings; BRANZ: Porirua, New Zealand, 2004.

3. Cosgroves Ltd. McDougall House Fire Strategy Report; Issue D; Cosgroves Ltd.: Christchurch, New Zealand, 2014.

4. Fulton Ross Team Architects. McDougall House Heritage Report; Fulton Ross Team Architects: Christchurch, New Zealand, 2013.

5. Pau, D.; Duncan, C.; Fleischmann, C. Fire Protection and Fire Safety Design of New Zealand Heritage Building. Fire Science and Technology 2018. In Proceedings of the 11th Asia-Oceania Symposium on Fire Science and Technology, Taipei, Taiwan, 21-25 October 2018; Springer: Singapore.

6. Lewis \& Barrow Ltd. McDougall House Earthquake Assessment; Lewis \& Barrow Ltd.: Christchurch, New Zealand, 2012.

7. Ministry of Business, Innovation and Employment. C/VM2 Verification Method: Framework for Fire Safety Design; Amendment 5; Ministry of Business, Innovation and Employment: Wellington, New Zealand, 2017.

8. Building Act 2004. Available online: http://legislation.govt.nz/act/public/2004/0072/144.0/DLM306036.html (accessed on 5 June 2019).

9. Ministry of Business, Innovation and Employment. Extract from the New Zealand Building Code; Ministry of Business, Innovation and Employment: Wellington, New Zealand, 2012.

10. Ministry of Business, Innovation and Employment. C/AS1-C/AS7 Acceptable Solutions; Amendment 4; Ministry of Business, Innovation and Employment: Wellington, New Zealand, 2017. 
11. Wade, C.; Beever, P.; Fleischmann, C.; Lester, J.; Lloydd, D.; Moule, A.; Saunders, N.; Thorby, P. Developing Fire Performance Criteria for New Zealand's Performance Based Building Code. In Proceedings of the Fire Safety Engineering International Seminar, Paris, France, 26-27 April 2007.

12. Fleischmann, C.M. Is Prescription the Future of Performance-Based Design? Fire Safety Science. In Proceedings of the 10th International Symposium on Fire Safety Science, College Park, MD, USA, 19-24 June 2011.

13. National Fire Protection Association. Performance-Based Option. In NFPA 101 Life Safety Code; 2018 ed.; National Fire Protection Association: Quincy, MA, USA, 2018; Chapter 5; pp. 44-48.

14. Australian Building Codes Board. International Fire Engineering Guidelines; 2005 ed.; Australian Building Codes Board: Canberra, Australia, 2005.

15. Chartered Institution of Building Services Engineers. CIBSE. Guide E: Fire Engineering, 2nd ed.; Chartered Institution of Building Services Engineers: London, UK, 2003.

16. Standards New Zealand. NZS 4512:2010 Fire Detection and Alarm Systems in Buildings; Standards New Zealand: Wellington, New Zealand, 2010.

17. Standards New Zealand. NZS 4541:2013 Automatic Fire Sprinkler Systems; Standards New Zealand: Wellington, New Zealand, 2013.

18. Ministry of Business, Innovation and Employment. Commentary for Building Code Clauses C1-C6 and Verification Method C/VM2; Ministry of Business, Innovation and Employment: Wellington, New Zealand, 2013.

19. International Organization for Standardization. ISO 5660-1:2015 Reaction-to-Fire Tests-Heat Release, Smoke Production and Mass Loss Rate-Part 1: Heat Release Rate (Cone Calorimeter Method) and Smoke Production Rate (Dynamic Measurement), 3rd ed.; International Organization for Standardization: Geneva, Switzerland, 2015.

20. International Organization for Standardization. ISO 9705-1:2016 Reaction to Fire Tests-Room Corner Test for Wall and Ceiling Lining Products-Part 1: Test Method for a Small Room Configuration, 1st ed.; International Organization for Standardization: Geneva, Switzerland, 2016.

21. International Organization for Standardization. ISO 9239-1:2010 Reaction to Fire Tests for Floorings—Part 1: Determination of the Burning Behaviour Using a Radiant Heat Source, 3rd ed.; International Organization for Standardization: Geneva, Switzerland, 2010.

22. Standards New Zealand. NZS 4510:2008 Fire Hydrant Systems for Buildings; Standards New Zealand: Wellington, New Zealand, 2008.

23. Wade, C.; Baker, G.; Frank, K.; Harrison, R.; Spearpoint, M. B-RISK 2016 User Guide and Technical Manual, 3rd ed.; BRANZ: Porirua, New Zealand, 2016.

24. Wade, C.A. Room Size Limits when Using a Fire Zone Model for Smoke-Filing Calculations; BRANZ: Porirua, New Zealand, 2013.

25. Gwynne, S.M.V.; Rosenbaum, E.R. Employing the Hydraulic Model in Assessing Emergency Movement. In SFPE Handbook of Fire Protection Engineering, 5th ed.; Hurley, M.J., Daniel, G., Eds.; Springer: New York, NY, USA, 2016; pp. 2115-2151.

(C) 2019 by the authors. Licensee MDPI, Basel, Switzerland. This article is an open access article distributed under the terms and conditions of the Creative Commons Attribution (CC BY) license (http://creativecommons.org/licenses/by/4.0/). 